\title{
Vertical growth and short-shoot demography of Syringodium filiforme in outer Florida Bay, USA
}

\author{
W. Judson Kenworthy*, Arthur C. Schwarzschild** \\ Beaufort Laboratory, NMFS, NOAA, 101 Pivers Island Road, Beaufort, North Carolina 28516, USA
}

\begin{abstract}
The vertical growth, short-shoot age structure, and demography of a Syringodium filiforme population were examined at 3 sites in a large meadow in outer Florida Bay, USA. Based on in situ marking experiments, we determined that the first 3 or 4 leaves on a short-shoot are produced in $\leq 45 \mathrm{~d}$; thereafter new leaves are formed about every $40 \mathrm{~d}$. We were able to confirm this estimate of leaf plastochrone interval (leaf PI) by examining the alternating internodal sequences resulting from differential growth of the vertical stems. Analysis of short-shoot age in leaf PI versus frequency histograms also indicated that each short-shoot produces approximately 12 leaves during the first year of growth and 9 leaves each year thereafter. Short-shoot age is skewed toward younger ages, with a median short-shoot age of approximately $0.6 \mathrm{yr}$, maximum age of $3.5 \mathrm{yr}$, and very few short-shoots living beyond 2.5 yr. Short-shoot recruitment appeared nearly continuous during the 3 yr study period. The vertical stem internodes were very large, ranging in length from 0.1 to $7.5 \mathrm{~cm}$ and averaging $2.1 \mathrm{~cm}$. Vertical stem growth was independent of the sediment surface, raising photosynthetic tissue 25 to $60 \mathrm{~cm}$ above the sediments and forming a multidimensional shoot canopy at an average rate of $17 \mathrm{~cm}$ $\mathrm{yr}^{-1}$ We determined that during the first year of life short-shoots could produce upwards of $25 \mathrm{~cm}$ of vertical stem. The vertical stem growth rate of $S$. filiforme is, therefore, among the highest reported for any species of seagrass. The developing techniques of seagrass demography proved to be valuable tools for analyzing the growth dynamics and population structure of $S$. filiforme in outer Florida Bay.
\end{abstract}

KEY WORDS: Seagrass - Syringodium filiforme - Vertical growth - Age - Demography C Competition Florida Bay

\section{INTRODUCTION}

Seagrasses are rhizomatous clonal plants with differentiated meristematic tissue enabling them to grow vegetatively along both horizontal (plagiotrophic) and erect (orthotrophic) axes (Tomlinson 1974). Division of the plagiotrophic rhizome apical meristem is the primary means of vegetative reproduction and horizontal expansion of seagrass clones. Nearly all horizontal growth yields erect short-shoots with either photosynthetic leaf tissue or flowers, while vertical short-shoot growth maintains the leaves and reproductive tissue above the sediment surface, ensuring their illumination and the dispersal or capture of waterborne pollen.

\footnotetext{
-E-mail: jkenworthy@hatteras.bea.nmfs.gov

-Present address: Department of Environmental Sciences, University of Virginia, Charlottesville, Virginia 22903, USA
}

Vertical growth of seagrasses occurs by stem, leaf, and sheath elongation, or, in the case of some species, the vertical extension of specialized reproductive organs. The vertical meristems can divide to produce new short-shoots or flowers as well as actively growing rhizomes which reconstruct the same axes as the horizontal rhizomes buried in the sediment (Fig. 1) (den Hartog 1970, Cambridge et al. 1983, Caye \& Meinez 1985. Kuo et al. 1987). This vertical growth habit can form tall, multidimensional shoot canopies which influence local hydrodynamics, promote sedimentation, and facilitate resource acquisition in the water column (Duarte et al. 1996). Additionally, the fragmentation of the vertically growing meristems is thought to be a mechanism for sexual and vegetative dispersal of some species (den Hartog 1970, Kuo et al. 1987).

The extent of differentiation between horizontal and vertical axes varies widely among seagrass genera and 


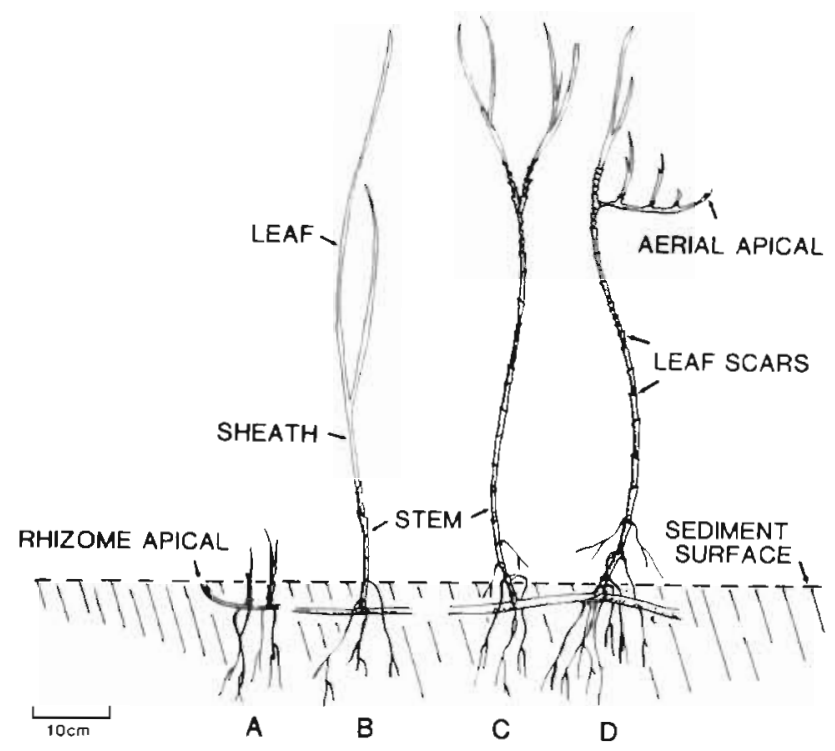

Fig. 1. Growth form of a Syringoduim fillforme long-shoot with annotations for specific anatomical features of the plant. (A) horizontal rhizome apical meristem with 2 young shortshoots with leaf PI (plastochrone interval) $=3$ and 4 ; (B) shortshoot with leaf $\mathrm{PI}=8$; $(\mathrm{C})$ branched shoot with multiple apices and leaf $\mathrm{PI}=28$; (D) branched short-shoot with a newly formed aerial rhizome apical and 3 short-shoots. Also shown is the location of the sediment surface

even among species within a genus (Tomlinson 1974, Kuo et al. 1987, Duarte et al. 1994, Duarte et al. 1996). The smallest seagrasses, e.g. Halophila decipiens (Ostenfeld) and Halophila ovalis (R. Brown), do not have highly differentiated meristems and grow on small prostrate stems elevated only 3 to $5 \mathrm{~cm}$ above the sediment surface. Lack of differentiated meristems does not necessarily constrain vertical growth, as some of the larger undifferentiated species form tall canopies by sheath and leaf elongation. For example, it is not uncommon to find leaves of Enhalus acoroides (Linnaeus f.) with lengths exceeding $0.5 \mathrm{~m}$ (Vermaat et al. 1995). Likewise, the high degree of variation in canopy height for Zostera marina (Linnaeus), another undifferentiated species, results from a wide range of morphological plasticity in leaf and sheath lengths (Dennison \& Alberte 1986).

Seagrasses with highly differentiated rhizomes express several forms of vertical growth. The vertical stems of Cymodocea serrulata (R. Brown) normally grow above the sediment surface (Vermaat et al. 1995), while a closely related species, Cymodocea nodosa (Ucria), maintains its vertical meristems at, or very near, the sediment surface (Marba \& Duarte 1994). Thalassia testudinum (Banks ex Konig) also maintains its vertical meristem near the sediment surface, to the extent that sediment accretion leads to increased vertical stem growth (Gallegos et al. 1993, Marba \& Duarte
1994, Marba et al. 1994). Where vertical growth keeps up with sediment accumulation, $T$. testudinum traps sediments and forms elevated mudbanks which modify local hydrography (Zieman 1982).

For Thalassia testudinum and Cymodocea nodosa, vertical stem growth and sediment dynamics are tightly coupled, because there is also a negative relationship between sediment erosion and seagrass growth and survival (Marba et al. 1994, Marba \& Duarte 1995). Evidently, these 2 species must maintain their vertically growing meristems near the sediment surface to avoid burial of photosynthetic tissue and minimize physical damage to the short-shoot (Marba et al. 1994, Duarte et al. 1997, Terrados 1997). However, it is not well understood why other highly differentiated species, e.g. Cymodocea serrulata (R. Brown), Thalassodendron cilitatum (Forsskal), Amphibolis antarctica (Labill.) Sonder et. Aschers., and Syringodium filiforme (Kutzing), lack this strict coupling and have short-shoot meristems which grow vertically above the sediment surface. It was hypothesized that the orientation of leaves higher up into the more illuminated portion of the water column may impart advantages to species capable of this type of vertical growth (Vermaat et al, 1995, Duarte et al. 1996). By modifying canopy structure, enhancing sediment accretion and facilitating resource acquisition in the water column, the outcome of competitive interactions between 2 co-occurring species (e.g. Williams 1987) may be affected by vertical growth which is uncoupled from sediment surface dynamics.

The benefits of vertical growth may be accompanied by additional physiological costs, especially if the growth is non-photosynthetic stem tissue. Stem tissue raises whole-plant respiration (Fourqurean \& Zieman 1991) and increases the distance between photosynthetic portions (leaves) of individual short-shoots in a clone. Clonal integration is an important process in which interconnected short-shoots on a rhizome share resources and support the growth of other ramets and meristematic tissue (Harrison 1978, Dawes \& Lawrence 1980, Libes \& Boudouresque 1987, Tomasko \& Dawes 1989, Terrados et al. 1997). As the distance between the leaves on adjacent short-shoots increases, there is likely to be a higher physiological cost associated with the translocation of materials among the ramets in a clone.

Syringodium filiforme is 1 of 3 important large-bodied tropical seagrasses widely distributed throughout the southeastern U.S., Gulf of Mexico, and Caribbean Sea. It develops meadows in a wide variety of environments, ranging from protected coastal lagoons with thick unconsolidated sediments and moderately stable hydrodynamic conditions (Kenworthy \& Fonseca 1996) to oceanic environments with high energy regimes and 
thin sediment veneers (Patriquin 1975). With a highly differentiated rhizome architecture (Tomlinson 1974) (Fig. 1) and a relatively fast horizontal growth rate (Gallegos et al. 1994), S. filiforme meadows stabilize sediments and initiate the formation of elevated mudbanks, suggesting that vertical stem growth may enhance sediment stability.

In this paper we quantify the rates of vertical growth of Syringodium filiforme in a relatively large meadow $\left(-600-800 \mathrm{~km}^{2}\right)$ located on a shallow carbonate shelf in the southeastern Gulf of Mexico just outside Florida Bay, Florida, USA (Fig. 2). Using recently developed short-shoot aging and reconstruction techniques (Duarte et al. 1994. Gallegos et al. 1994), we examine demographic characteristics of the $S$. filiforme population and seasonal and annual cycles of stem growth, and we estimate growth rates of vertical stems relative to the growth of other plant components and other seagrasses. We also discuss the implications of vertical growth relative to competition with other species and the environmental conditions in the regional coastal ecosystem of South Florida. This large S. filiforme meadow stabilizes an estimated $10^{8} \mathrm{~m}^{3}$ of fine unconsolidated sediments, protecting coral reefs to the south and providing a complex habitat linking the southeastern Gulf of Mexico to Florida Bay and the Florida Keys reef tract.

\section{MATERIAL AND METHODS}

Study area. A previous survey established 6 permanent monitoring sites on the shallow limestone platform of outer Florida Bay. These sites fell along a water depth and bottom community gradient ranging from an inshore, shallow water area ( 1 to $2 \mathrm{~m}$ ) dominated by a dense Thalassia testudinum and finger coral community mixed with Syringodium filiforme through a medium depth ( 2 to $5 \mathrm{~m}$ ) dense $S$. filiforme community with sparse $T$. testudinum to a deep water $(>5 \mathrm{~m}$ ) site with a sparse, mixed community of Halodule wrightii (Ascherson), S. filiforme and Halophila spp. The present project used 3 of these study sites (sites 3,4 and 5) located in the medium depth, $S$. filiforme meadow. Site 3 was in $2.0-2.5 \mathrm{~m}$ water depth at $24^{\circ} 47.34^{\prime} \mathrm{N}$, $81^{\circ} 10.2^{\prime} \mathrm{W}$, site 4 in $3.0-3.5 \mathrm{~m}$ water depth at $24^{\circ} 48.80^{\prime} \mathrm{N}, 81^{\circ} 9.50^{\prime} \mathrm{W}$, and site 5 in $4.0-4.5 \mathrm{~m}$ water depth at $24^{\circ} 50.70^{\prime} \mathrm{N}, 81^{\circ} 10.73^{\prime} \mathrm{W}$ (Fig. 2). The meadow is dominated by a nearly monotypic cover of $S$. filiforme overlying a fine grained, unconsolidated carbonate sediment ranging from 22 to $30 \mathrm{~cm}$ in thick- ness. Interspersed within the $S$. filiforme meadow are relatively small patches of exposed bedrock occupied by calcareous algae, invertebrates, and sparse communities of $T$. testudinum and $H$. wrightii (Fourqurean et al. 1997). The offshore edge of the $S$. filiforme meadow extends to approximately 6 to $7 \mathrm{~m}$ water depth, where it grades into a relatively sparse community of $H$. wrightii and Halophila decipiens (Continental Shelf Associates, Inc and Geonex Martel, Inc. 1991, Iverson \& Bittaker 1986, Kenworthy unpubl. data).

Vertical growth. When the leaf scars on a seagrass short-shoot are recognizable, vertical stem growth can be used to reconstruct the entire chronological life of an individual short-shoot (Duarte et al. 1994). This is due to the one-to-one relationship between the formation of leaves and the leaf scar created at the insertion point on the vertical stem (Patriquin 1973, Brouns 1985, Duarte et al. 1994) (Fig. 1). If the time interval between the formation of new leaves is known (hereafter referred to as the leaf plastochrone interval or leaf PI; see Erickson \& Michelini 1957), we can estimate the age of a short-shoot and the growth rate of the vertical stem. In seagrass species that live longer than $1 \mathrm{yr}$, cyclic seasonal patterns of vertical rhizome internode lengths calibrated with independent measurements of the leaf PI can be used to back-calculate vertical growth rates (Gallegos et al. 1994, Vermaat et al. 1995, Duarte et al. 1996), thereby alleviating the need for continuous field measurements of leaf PJ or productivity. The leaf scars of individual Syringodium filiforme short-shoots are prominent and easily identified with internode distances ranging from 1 to $70 \mathrm{~mm}$, making this species relatively easy to age.

Leaf marking. To calibrate vertical internode sequences with chronological time, a leaf marking technique was used to measure the leaf PI for 
Syringodium filiforme at sites 3 and 4. In May 1994 we arbitrarily placed six $10 \times 20 \mathrm{~cm}$ galvanized wire quadrats in the $S$. filiforme meadow at each site. All of the short-shoots within the quadrats were marked by clipping the end of the youngest leaf so that the new leaves formed during the marking period could be identified. The marked short-shoots were recovered from sites 3 and 4, after 6 and 7 d respectively, by clipping the short-shoot stems at the sediment surface close to their attachment point on the horizontal rhizome. In October 1994 we placed six $10 \times 20 \mathrm{~cm}$ quadrats at site 4 only. All of the short-shoots within the quadrats were marked as above and recovered after a 17 d period. No $S$. filiforme leaf PI were estimated at site 5 . In the laboratory, the total number of marked short-shoots and total number of new leaves formed during the time period were recorded for each quadrat. The leaf plastochrone interval was calculated by the formula:

Leaf Plastrochrone Interval $=\frac{\text { days } \times \text { number of leaves marked }}{\sum \text { number of new leaves }}$

where Leaf Plastochrone Interval = days; days = number of days in marking period; leaves marked = total number of leaves on short-shoots marked in quadrat; and new leaves = new leaves formed on marked shortshoots between marking and recovery.

Determination of short-shoot formation rate and initial leaf PI. In October of 1995, Syringodium filiforme horizontal rhizome runners were collected from a disturbance site where all plant material had been removed 60 d earlier. Runners were collected by locating rhizome apical meristems growing in the disturbed area, gently freeing them from the sediments and following the rhizomes back to the edge of the disturbance area. The rhizomes were then clipped, and the runners, including associated short-shoots, were recovered. Only the longest runners found growing into the disturbance were collected to ensure that initiation of growth into the area had occurred soon after the disturbance event. In the laboratory, the number of short-shoots on each runner were counted. The position and age, in leaf Pl, of each short-shoot on the runners were also recorded. The short-shoot formation. rate was calculated for each runner using the following formula.

Short-shoot Formation Rate $=\frac{\text { days since distusbance }}{\text { number of short-shoots on a runner }}$

where Short-shoot Formation Rate = days shortshoot $^{-1}$; days since disturbance $=60 \mathrm{~d}$; and number of short-shoots on a runner = number of short-shoots formed on a runner since the disturbance event.

The rate at which the first few leaves on a shortshoot are formed was calculated by 2 methods. For the first method, we used 17 of the runners collected from the $60 \mathrm{~d}$ old disturbance site. The maximum possible age of the runners collected ( $60 \mathrm{~d}$ ) was divided by the number of leaf internodes (short-shoot age in leaf PI) of the oldest short-shoot on a runner. In the second method, the mean short-shoot formation rate ddays short-shoot ${ }^{-1}$ ) was divided by number of internodes on the youngest short-shoot (the age of the youngest short-shoot in leaf PI) on each runner. We also used a similar approach to calculate the initial leaf PI from data reported on 3 syringodium filiforme runners growing in a mesocosm experiment (Short et al. 1993).

Syringodium filiforme short-shoot age and demographics. In May 1994 and again in May 1996 we collected and aged $S$. filiforme short-shoots from sites 3, 4, and 5. In October 1994, April 1995, October 1995, and January 1997 we collected and aged $S$. filiforme from site 4 only. Plants were collected by arbitrarily placing a $50 \times 50 \mathrm{~cm}$ PVC quadrat over the grass bed and carefully excavating the entire sod of short-shoots, rhizomes, and roots with a dive knife. The sods were placed in a mesh bag, rinsed free of sediments, and returned to the lab. Three sods were collected from each site in May 1994 and 1996, and 3 sods were collected from site 4 at each of the additional sample dates.

In the laboratory each sod was carefully unwoven. and sorted into live short-shoots, flowering shortshoots, horizontal rhizome branches, aerial rhizome branches, horizontal rhizome apical meristems, and aerial rhizome apical meristems. The number of leaf scars, attached leaves, and age in total number of leaf PI were recorded for all live short-shoots with attachments to the horizontal rhizome. Histograms of age (in total number of leaf PI) of living short-shoots versus frequency were generated for each site and sample date, and were used to determine the mean, median, and maximum ages of Syringodium filiforme shortshoots in the sample population. The short-shoot age distributions were examined for seasonal differences (April-May vs October) and annual changes (1994 vs 1995 samples), and to look for age cohort peaks.

Independent estimates of leai PI. We independently verified our estimates of leaf PI by 2 additional methods. For the first method we calculated the average number of leaf plastochrone intervals between cohort peaks on the short-shoot age (leaf PI) versus frequency histograms (Duarte et al. 1994, Durako 1994). For the second independent estimate we subsampled the oldest short-shoots found at each site from the May 1994 samples, and examined the internode length cycles (nearest $0.1 \mathrm{~cm}$ ) for seasonal growth patterns. The intermodal length sequences of short and long internodes indicate the seasonal patterns of leaf and node formation on a short-shoot during a $1 \mathrm{yr}$ period (Duarte 
et al. 1994, Gallegos et al. 1994). Only non-branching, vegetative short-shoots were selected for this particular analysis. Flowering and branched short-shoots were omitted because these life history events appear to affect the lengths of internodes immediately before and after branch or flower initiation.

Allocation of vertical growth. From the Syringodium filiforme sods collected at sites 3,4, and 5 in May 1994 ( $\mathrm{n}=73$ short-shoots) and at sites 3, 4 and 5 in May 1996 ( $n=1666$ short-shoots) we measured the vertical stem internode lengths, sheath lengths, longest leaf, and total short-shoot lengths of intact short-shoots. The vertical stem is defined as the tissue between the point where the short-shoot and horizontal rhizome intersect and the base of the leaf sheath (Fig. 1). The lengths were calibrated to chronological time and used to estimate annual short-shoot vertical growth. These age specific length data were used to examine the allocation of vertical growth among plant components for plants of different ages.

Biomass allocation in Syringodium filiforme. At each of the 3 study sites in May 1996 we collected 5 plant samples in the vegetated portion of the seagrass meadow using a $15 \mathrm{~cm}$ diameter PVC corer. The core was inserted 20 to $25 \mathrm{~cm}$ into the sediment or to the bedrock, whichever came first. The entire sediment plug and its associated plant material were extracted into a mesh bag. Each core was rinsed free of sediment and sorted by species into short-shoots, leaves, flowers, vertical stems, and belowground roots-rhizomes. The number of short-shoots and flowers were counted and the sorted plant material was rinsed with $5 \%$ phosphoric acid to remove adhering carbonates and dried to a constant weight (nearest $0.000 \mathrm{~g}$ ) at $60^{\circ} \mathrm{C}$.

Table 1. Leaf plastochrone interval (Pl) for Syringodium filiforme at 2 sites and 2 sample dates in outer Florida Bay

\begin{tabular}{|c|c|c|c|c|c|}
\hline Date & Site & $\begin{array}{l}\text { No. of } \\
\text { marked } \\
\text { shoots }\end{array}$ & $\begin{array}{l}\text { No. of } \\
\text { new } \\
\text { leaves }\end{array}$ & $\begin{array}{l}\text { No. of } \\
\text { days }\end{array}$ & Pl \\
\hline May 1994 & 3 & 67 & 08 & 6 & 50.3 \\
\hline May 1994 & 3 & 38 & 05 & 6 & 45.6 \\
\hline May 1994 & 3 & 77 & 15 & 6 & 30.8 \\
\hline May 1994 & 4 & 84 & 22 & 7 & 26.7 \\
\hline May 1994 & 4 & 64 & 22 & 7 & 20.4 \\
\hline May 1994 & 4 & 89 & 17 & 7 & 36.6 \\
\hline Oct 1994 & 4 & 71. & 28 & 17 & 43.1 \\
\hline Oct 1994 & 4 & 98 & 40 & 17 & 41.7 \\
\hline Oct 1994 & 4 & 73 & 30 & 17 & 41.4 \\
\hline \multirow[t]{2}{*}{ Oct 1994} & 4 & 59 & 20 & 17 & 50.2 \\
\hline & & & & $\begin{array}{r}\text { Lean PI: } \\
\text { SE: } \\
\text { Range: }\end{array}$ & $\begin{array}{c}38.7 \\
3.2 \\
20.4-50.3\end{array}$ \\
\hline
\end{tabular}

\section{RESULTS}

\section{Leaf marking and leaf plastochrone interval}

All of the quadrats with marked plants were recovered from sites 3 and 4 in May 1994. Only 4 of the 6 quadrats placed at site 4 were successfully recovered in October 1994. The leaf PI ranged between 20.4 and 50.3, with an average of $38.7 \mathrm{~d}$ (Table 1). There were no significant differences in leaf PI between sample locations or dates (ANOVA p > 0.05), suggesting that a Syringodium filiforme short-shoot produces approximately 9.4 leaves $\mathrm{yr}^{-1}(365 / 38.7)$ in this population.

\section{Determination of short-shoot formation rate and initial leaf PI}

Seventeen Syringodium filiforme horizontal rhizome runners were successfully collected from the $60 \mathrm{~d}$ old disturbance site where we had removed all plant material (Table 2). The mean number of short-shoots formed on each runner was $6.1 \pm 0.3$, yielding a mean short-shoot formation rate of $10.2 \pm 0.5 \mathrm{~d}$ short-shoot ${ }^{-1}$. The mean leaf PI calculated from the age of the oldest short-shoot was $14.6 \pm 0.5 \mathrm{~d}$. The mean initial leaf PI calculated using the short-shoot PI and the ages of the youngest short-shoots was $8.2 \pm 0.7 \mathrm{~d}$. The initial leaf PI determined from 3 rhizome runners grown in the mesocosm experiment (Short et al. 1993) was $8.1 \mathrm{~d}$. These results suggest that the first few leaves of $S$. filiforme short-shoots are produced at a much higher rate than that measured for mature short-shoots using the leaf marking technique.

\section{Syringodium filiforme short-shoot age and demographics}

The age frequency distributions on all sampling dates were skewed toward the younger age categories (Figs. $3 \& 4$, Table 3). Young plants were present in spring, fall and winter age distributions, suggesting that vegetative recruitment occurs throughout the year. The modal age tended to be around 4 or 5 leaf PI, with 3 exceptions where modes were present at 7,8 (site 4 May 1994 and 1996), and 9 leaf PI (site 3, May 1996) (Table 3). The median ages of live short-shoots ranged from 7 to 9 leaf PI and were generally lower than the mean ages, reflecting the skewness of the distribution. The maximum age recorded in the samples was 35 leaf PI (Table 3), and very few short-shoots live beyond 25 leaf PI.

There were no statistically significant differences between the age frequency distributions at sites 3,4 , 
Table 2. Demographic data for Syringodium filiforme horizontal rhizome runners collected from a $60 \mathrm{~d}$ old disturbance site. $\mathrm{B}=$ broken short-shoot. Shortshoot formation rate $=60 \mathrm{~d} \div$ number of short-shoots per runner. Leaf PI1 $=$ $60 \mathrm{~d} \div$ age (in leaf PI) of oldest short-shoot. Leaf PI2 = Short-shoot formation rate $\div$ age (เn leaf PI) of youngest short-shoot

\begin{tabular}{|c|c|c|c|c|c|}
\hline $\begin{array}{c}\text { Number of } \\
\text { short-shoots } \\
\text { per } \\
\text { runner }\end{array}$ & $\begin{array}{c}\text { Age (leaf } \\
\text { PIl of } \\
\text { oldest } \\
\text { short-shoot }\end{array}$ & $\begin{array}{c}\text { Age (leaf } \\
\text { PI) of } \\
\text { youngest } \\
\text { short-shoot }\end{array}$ & $\begin{array}{l}\text { Short-shoot } \\
\text { formation rate } \\
\text { (d short- } \\
\left.\text { shoot }^{-1}\right)\end{array}$ & $\begin{array}{l}\text { Leaf PI1 } \\
\left(\text { d leaf }^{-1}\right)\end{array}$ & $\begin{array}{l}\text { Leaf PI2 } \\
\left(\text { d leaf }^{-1}\right)\end{array}$ \\
\hline 6 & 4 & 1 & 10.0 & 15 & 10.2 \\
\hline 6 & 4 & 2 & 10.0 & 15 & 5.1 \\
\hline 6 & 4 & 1 & 10.0 & 15 & 10.2 \\
\hline 6 & 4 & 2 & 10.0 & 15 & 5.1 \\
\hline 7 & 4 & 1 & 8.6 & 15 & 10.2 \\
\hline 9 & 5 & 1 & 6.7 & 12 & 10.2 \\
\hline 4 & 4 & 3 & 15.0 & 1.5 & 3.4 \\
\hline 5 & 4 & 2 & 12.0 & 15 & 5.1 \\
\hline 6 & 4 & 2 & 10.0 & 15 & 5.1 \\
\hline 7 & 5 & 1 & 8.6 & 12 & 10.2 \\
\hline 8 & 5 & 1 & 7.5 & 12 & 10.2 \\
\hline 7 & 4 & 1 & 8.6 & 15 & 10.2 \\
\hline 5 & 3 & 1 & 12.0 & 20 & 10.2 \\
\hline 5 & 4 & 1 & 12.0 & 15 & 10.2 \\
\hline 6 & 4 & 1 & 10.0 & 15 & 10.2 \\
\hline 5 & 4 & 2 & 12.0 & 15 & 5.1 \\
\hline 6 & 5 & B & 10.0 & 12 & - \\
\hline \multicolumn{6}{|l|}{ Mean $\pm \mathrm{SE}$} \\
\hline $6.1 \pm 0.3$ & $4.2 \pm 0.1$ & $1.4 \pm 0.2$ & $10.2 \pm 0.5$ & $14.6 \pm 0.5$ & $8.2 \pm 0.7$ \\
\hline
\end{tabular}
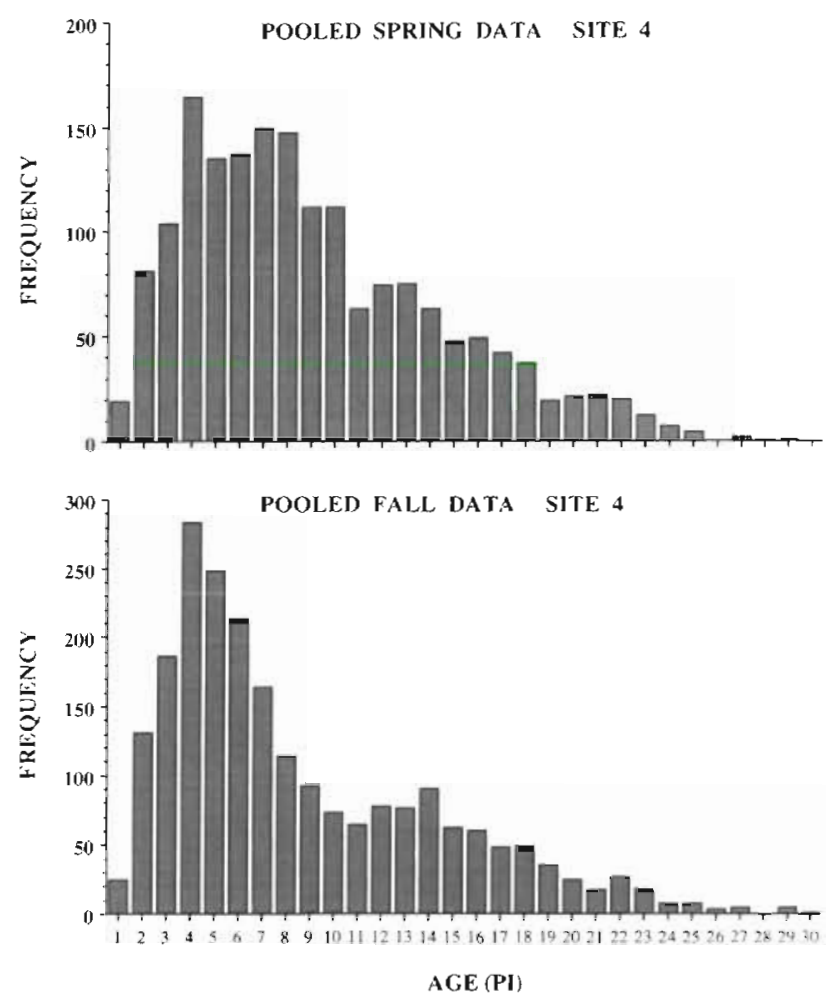

Fig. 3. Syringodium filiforme short-shoot age frequency distributions (in leaf plastochrone intervals) for the pooled 1994 and 1995 spring $(n=1719)$ and fall $(n=2204)$ data from site 4 and 5 in May 1994 ( $\mathrm{p}>0.05$, Kolmogorov-Smirnov goodness of fit test), therefore we pooled the replicate samples from site 4 and tested the frequency distributions for seasonal and annual differences just at site 4. In both the 1994 and 1995 samples there were significant differences between spring (April-May samples) and fall (October samples) ( $p=0.0001$, Kolmogorov-Smirnov goodness of fit test) (Fig. 3). No significant annual differences were seen when the May 1994 distribution was tested against April $1995(p=0.26)$, or when the 2 October distributions were compared ( $\mathrm{p}=$ 0.37 ).

\section{Independent estimates of PI}

Cohort peaks can be seen at $4,7,12$, 16 and 21 leaf $\mathrm{PI}$ in the pooled spring age distribution and at $4,12,14,18$ and 22 leaf $P I$ in the pooled fall distribution at site 4 (Fig. 3). The average distance between cohort peaks from all sites and sample dates was $4.5 \pm 0.5$ leaf PI (Table 3). Assuming 2 recruitment peaks per year, as was observed for populations of Thalassia testudinum growing nearby in Florida Bay (Durako 1994), we estimate that Syringodium filiforme short-shoots produce approximately 9 leaves $\mathrm{yr}^{-1}$. This value agrees closely with the results obtained by the leaf marking technique.

For a second independent estimate of leaf PI, we graphically examined the cyclic pattern of stem internode length sequences on 90 short-shoots from sites 3 , 4. and 5 sampled in May 1994 and May 1996 (Fig. 5, Table 4). If we assume that the alternating length cycles represent annual cycles of leaf formation, then the nodes cycle ${ }^{-1}$ should approximate the leaf PI (Duarte et al. 1994). For illustrative purposes we present only a single graph showing a double $y$-axes plot of short-shoot age in leaf PI $(x)$ versus internode length $\left(y_{1}\right)$ and cumulative internode length $\left(y_{2}\right)$ for one of the 90 short-shoots analyzed (Fig. 5). This is the entire growth history of the vertical stem on a single shortshoot 27 leaf PI old. In this example we see a typical pattern for the 90 short-shoots measured, in which the first 3 to 5 internodes are short ( 1.0 to $2.5 \mathrm{~cm}$ ), and correspond with the initially higher leaf PI discussed above. These are followed by a sharp increase in the internode length up to about the 8 th leaf PI. The internode length then declines and repeats the pattern 
of increase up to the 16th leaf PI, followed by another decline. Typically, the amplitude of the first peak was higher than the second peak for most of the short-shoots. The last 7 internodes were usually short and nearly always the same size.

To calculate the number of leaf PI cycle $\mathrm{c}^{-1}$ we have to account for the rapid rate of leaf and node formation in the initial group of nodes on young short-shoots. As was shown for Thalassia testudinum (Patriquin 1973) and Syringodium isoetifolium (Brouns 1985), the first few leaves on a $S$. filiforme short-shoot are also produced more rapidly than the older leaves. We confirmed that the first few leaves on $S$. filiforme short-shoots were produced in $\sim 32$ to $45 \mathrm{~d}$ by analyzing short-shoot growth on rhizome runners of a known age (Table 2), and calculations from short-shoots grown in

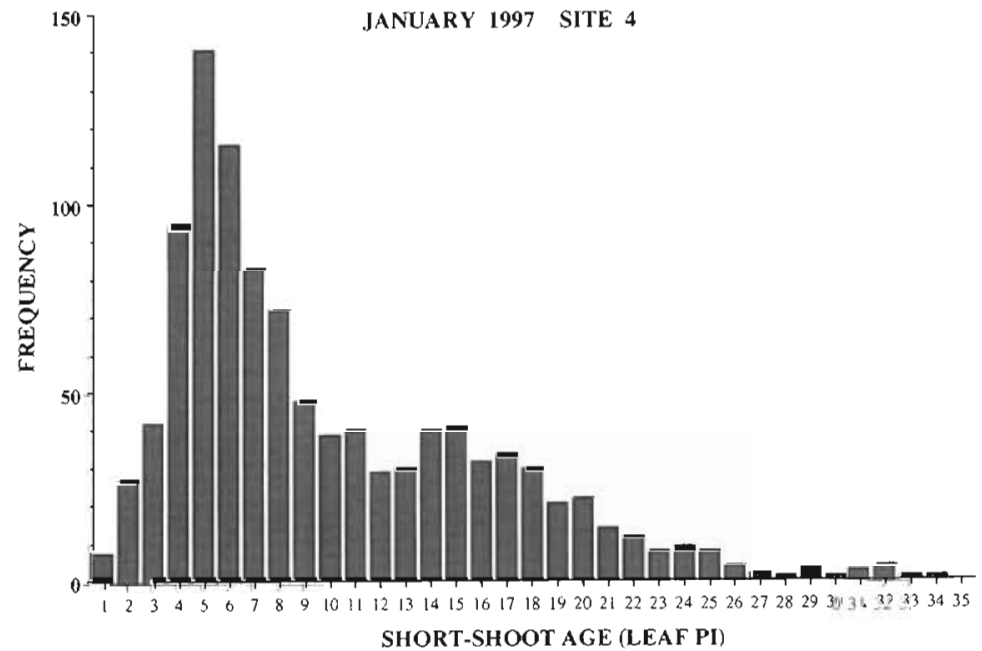

Fig. 4. Syringodium filiforme short-shoot age frequency distribution (in leaf plastochrone intervals) for site 4 in January $1997(n=1061)$

Table 3. Demographic characteristics of a population of Syringodium filiforme short-shoots sampled at 3 sites in outer Florida Bay between May 1994 and January 1997. Flower data is a compilation of the flowers collected and aged from the April 1995 site 4 , May 1996 sites 3, 4 and 5, and the January 1997 samples. n: no. of short-shoots aged

\begin{tabular}{|c|c|c|c|c|c|c|c|}
\hline Sample date & Site & $\mathrm{n}$ & $\begin{array}{c}\text { Mean } \\
\text { age (PI) }\end{array}$ & $\begin{array}{l}\text { Median } \\
\text { age (PI) }\end{array}$ & $\begin{array}{l}\text { Mode } \\
(\mathrm{PI})\end{array}$ & $\begin{array}{l}\text { Maximum } \\
\text { age }(\mathrm{PI})\end{array}$ & $\begin{array}{l}\text { Mean distance } \\
\text { (PI) between } \\
\text { cohort peaks }\end{array}$ \\
\hline May 1994 & $\begin{array}{l}3 \\
4 \\
5\end{array}$ & $\begin{array}{l}406 \\
637 \\
149\end{array}$ & $\begin{array}{l}9.1 \\
9.2 \\
9.0\end{array}$ & $\begin{array}{l}9 \\
8 \\
8\end{array}$ & $\begin{array}{l}4 \\
8 \\
5\end{array}$ & $\begin{array}{l}25 \\
29 \\
23\end{array}$ & $\begin{array}{l}2.8 \\
4.8 \\
5.0\end{array}$ \\
\hline Oct 1994 & 4 & 1080 & 8.7 & 7 & 4 & 33 & 5.0 \\
\hline Apr 1995 & 4 & 1083 & 9.1 & 8 & 4 & 31 & 4.0 \\
\hline Oct 1995 & 4 & 1125 & 8.4 & 7 & 4 & 30 & 9.0 \\
\hline Pooled spring & 4 & 2275 & 9.1 & 8 & 4 & 31 & 4.3 \\
\hline Pooled fall & 4 & 2205 & 8.6 & 7 & 4 & 33 & 4.5 \\
\hline May 1996 & $\begin{array}{l}3 \\
4 \\
5\end{array}$ & $\begin{array}{r}346 \\
1020 \\
301\end{array}$ & $\begin{array}{r}9.3 \\
11.6 \\
10.1\end{array}$ & $\begin{array}{l}9 \\
9 \\
9\end{array}$ & $\begin{array}{l}9 \\
7 \\
4\end{array}$ & $\begin{array}{l}26 \\
35 \\
24\end{array}$ & $\begin{array}{l}3.7 \\
4.0 \\
3.2\end{array}$ \\
\hline Jan 1997 & 4 & 1061 & 9.9 & 8 & 5 & 34 & 3.9 \\
\hline Flowers & - & 422 & 11.1 & 9 & 7 & $\begin{array}{l}26 \\
\text { Mean } \pm \mathrm{SE}\end{array}$ & $\begin{array}{c}- \\
4.5 \pm 0.5\end{array}$ \\
\hline
\end{tabular}

Table 4. Summary data for the Syringodium filiforme vertical stem nodes formed per initial group, nodes per cycle, nodes formed in the first year, and the height of vertical stems at the end of the first year of growth from 3 sites in outer Florida Bay. n: no. of short-shoots measured

\begin{tabular}{|lcccccc|}
\hline Date & Site & $\mathrm{n}$ & $\begin{array}{c}\text { No. of nodes } \\
\text { per initial group }\end{array}$ & $\begin{array}{c}\text { No. of nodes } \\
\text { per cycle }\end{array}$ & $\begin{array}{c}\text { No. of nodes } \\
\text { per first year }\end{array}$ & $\begin{array}{c}\text { Height }(\mathrm{cm}) \text { at } \\
1 \text { yr }\end{array}$ \\
\hline May 1994 & 3 & 23 & $3.9 \pm 0.3$ & $8.6 \pm 0.3$ & $12.5 \pm 0.5$ & $35.1 \pm 1.6$ \\
May 1994 & 4 & 25 & $3.1 \pm 0.2$ & $8.4 \pm 0.4$ & $11.5 \pm 0.4$ & $26.1 \pm 1.0$ \\
May 1994 & 5 & 25 & $3.5 \pm 0.2$ & $8.8 \pm 0.5$ & $12.3 \pm 0.5$ & $36.4 \pm 2.1$ \\
Mean \pm SE & & & $3.5 \pm 0.1$ & $8.6 \pm 0.1$ & $12.2 \pm 0.2$ & $32.5 \pm 1.8$ \\
\hline
\end{tabular}




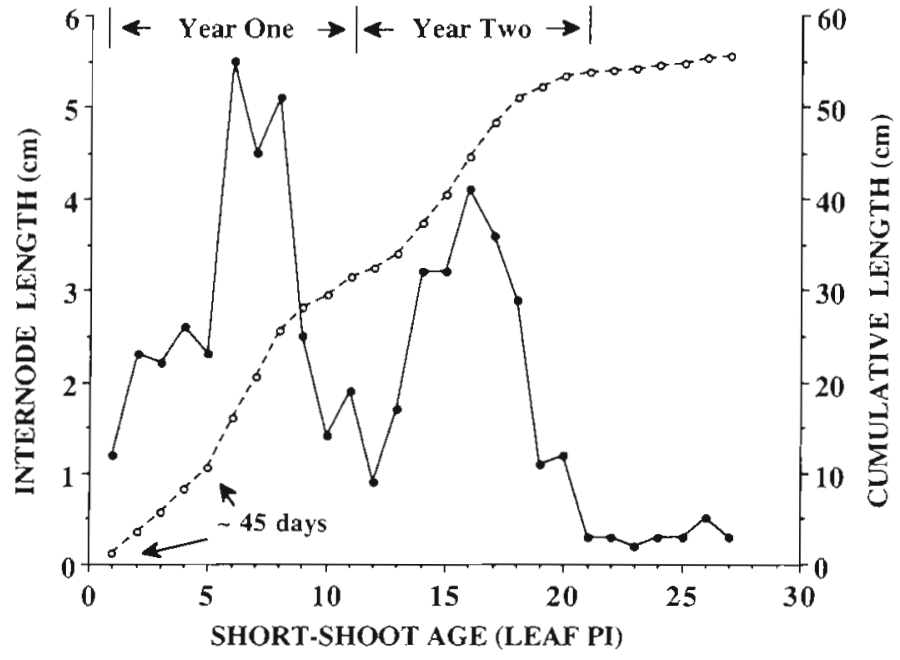

Fig. 5. Plot of Syringodium filiforme short-shoot age (in leaf plastochrone intervals) versus vertical stem internode length (•) and vertical stem cumulative internode length $(0)$

a mesocosm (Short et al. 1993). The leaf PI for the first 3 or 4 nodes is between 8 and $15 \mathrm{~d}$, after which the leaf PI increases corresponding to the rapid maturation of a short-shoot. The mean number of nodes in the initial group on 90 short-shoots we analyzed was 3.5 short-shoot ${ }^{-1}$, while the nodes cycle ${ }^{-1}$ averaged 8.6 (Table 4, Fig. 5). Given the rapid production of the initial nodes, we estimate that the first year of growth is represented by an average of 12.2 nodes $(3.5+8.7)$ (Table 4 ). If we subtract the initial node group from the first cycle, the 2 cycles average 8.6 nodes $\mathrm{cycle}^{-1}$ (Table 4). Averaging the 3 methods, we estimate that S. filiforme short-shoots produce approximately 9 leaves short-shoot ${ }^{-1} \mathrm{yr}^{-1}$, for a leaf PI of $40 \mathrm{~d}$. Accounting for the rapid formation of the first nodes followed by a leaf PI of $40 \mathrm{~d}$, we can now convert the leaf PI scale into chronological time for estimating growth rates of vertical stems, sheaths, and leaves.

\section{Allocation of vertical growth}

The internodes on the vertical stems of individual short-shoots ranged in size from 0.1 to $7.5 \mathrm{~cm}$. The cycle of internode growth alternated between initial minimum lengths associated with the first few internodes, seasonal maximum values and seasonal minimum values (Fig. 5). Maximum lengths often exceeded $3 \mathrm{~cm}$ and normally the first cycle peak exceeded the maximum value of the second peak. Generally, the last few older internodes on short-shoots $>2$ yr old were similar in size and shorter than previous minima. Overall, the average internode lengths for all short-shoots measured was $2.09 \pm 0.05 \mathrm{~cm}(\mathrm{n}=1.22)$.
The average total length of Syringodium filiforme short-shoots $(n=1170)$ reached asymptotic values between 45 and $60 \mathrm{~cm}$ at all 3 sites (Fig. 6). Short-shoots attained near maximum total lengths during the first year of growth when leaves reached maximum lengths, contributing the largest proportion of total shortshoot length, especially between leaf PI 4 and 10. For plants older than $1 \mathrm{yr}$ the stem contributed a larger proportion of the total length, as the average length of leaves on the older short-shoots reached nearly asymptotic values while stem length continued to increase through the second year of growth until about 26 leaf PI. Changes in the mean length of the sheaths corresponded with the leaves, but were a much smaller component of the total length.

The total biomass of Syringodium filiforme was 248, 827, and $603 \mathrm{~g} \mathrm{dw} \mathrm{m}^{-2}$ at sites 3,4 and 5, respectively (Fig. 7). Averaged over the 3 sites, vertical stems comprised $37 \%$ of the total. At all 3
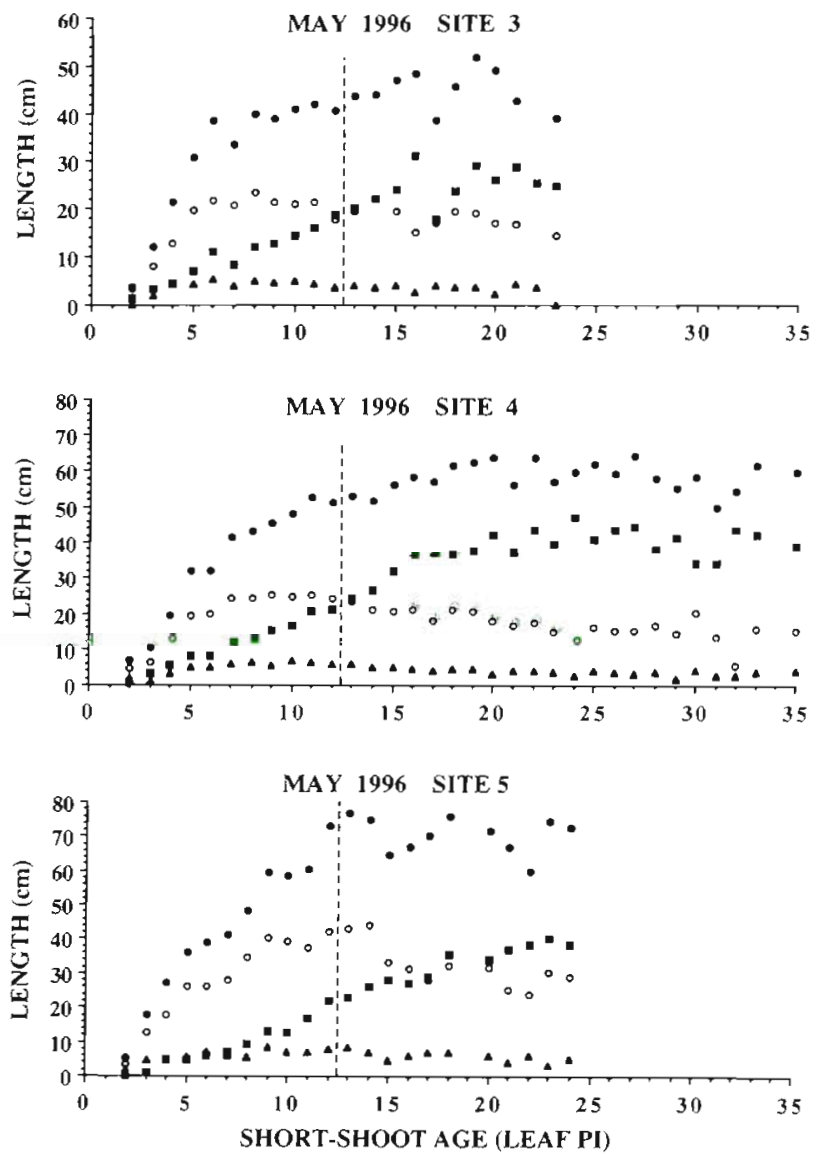

Fig. 6. Allocation of Syringodium filiforme vertical growth to leaves (0), sheaths ( $\mathbf{\Lambda})$, stems ( $\mathbf{0})$, and total short-shoot length (•). Dashed vertical line indicates approximately 1 yr on the leaf PI scale 
sites the stem biomass exceeded leaf biomass and, overall, stems accounted for $59 \%$ of the estimated aboveground biomass.

\section{Vertical stem growth rate}

We converted leaf PI into chronological time and calculated vertical stem growth rates at the 3 sites for short-shoots collected in May 1996. At the end of the first year of growth, stem lengths were $24.3,31.9$ and $30.0 \mathrm{~cm}$ at sites 3,4 , and 5 respectively, for an average growth rate of $28.7 \pm 1.3 \mathrm{~cm} \mathrm{yr}^{-1}$. This stem growth is similar to the stem heights recorded at the end of the first year of growth for the 73 plants we examined in 1994 (Table 4). For these 2 independent samples, stem growth rates in the first year ranged between 24 and $36 \mathrm{~cm} \mathrm{yr}^{-1}$. During the second year, stems grew at a rate of only $5.3 \pm 1.5 \mathrm{~cm} \mathrm{yr}^{-1}$. Thus, over a 2 yr period the plants sustained an average vertical growth rate of $\sim 17 \mathrm{~cm} \mathrm{yr}^{-1}$. Because of this vertical stem growth, the leaves on adjacent short-shoots connected to one another on a long-shoot may be separated by as much as 50 to $70 \mathrm{~cm}$ of vertical stem and rhizome.

\section{DISCUSSION}

\section{Leaf plastochrone interval and short-shoot age structure}

The 3 methods used to determine the leaf formation rate of Syringodium filiforme short-shoots older than 4 leaf PI were in very close agreement. The average leaf PI estimated directly by leaf marking ( 9.4 leaves short-shoot ${ }^{-1} \mathrm{yr}^{-1}$ ) (Table 1) was slightly higher than both the values estimated from the cohort peaks in the age frequency histograms assuming 2 cohort peaks per year (9.0 leaves short-shoot $\mathrm{yr}^{-1}$ ) (Fig. 3, Table 3) and the internode cycle analysis (8.7 leaves short-shoot ${ }^{-1}$ $\mathrm{yr}^{-1}$ ) (Table 4). As for the 2 other seagrasses which have been closely examined (Patriquin 1973, Brouns 1985), the first 3 or 4 leaves on a Syringodium filiforme short-shoot are formed in rapid succession ( -32 to $45 \mathrm{~d}$ ), with an initial leaf PI of approximately 8 to $15 \mathrm{~d}$. Thereafter, we estimate that a new leaf is formed every $40 \mathrm{~d}$ in this population. This rate is about one third faster than the $60 \mathrm{~d}$ leaf $P I$ reported for a $S$. filiforme population in a Mexican Caribbean lagoon calculated from vertical stem internode length sequences (Gallegos et al. 1994). The density and size of short-shoots were also different in the Florida population. Shortshoot density in the Mexican lagoon $\left(-7000 \mathrm{~m}^{-2}\right)$ exceeded the Florida population $\left(\sim 2000 \mathrm{~m}^{-2}\right)$ by more than a factor of 3 , while maximum short-shoot lengths $(16 \mathrm{~cm})$ were much smaller in the Mexican population (Fig. 6). A comparison of the 2 populations suggests a negative correspondence between short-shoot density and the size of plant modules. Clearly, these $2 \mathrm{~S}$. filiforme populations have distinctly different size and growth characteristics reflecting the high degree of morphological plasticity found in this species. These differences may suggest more than just a density dependent population response and they confirm that site specific calibrations of PI are necessary before attempting to reconstruct short-shoot growth and estimate the demographic characteristics of a $S$. filiforme population (sensu Durako 1994, Durako \& Duarte 1997, Jensen et al. 1997).

Other comparable data for Syringodium filiforme leaf PI can be derived from 2 independent studies near Fort Pierce, Florida. One study reported the growth history of the short-shoots on 3 horizontal rhizome runners in a mesocosm (Short et al. 1993). During $566 \mathrm{~d}$ of growth the oldest $S$. filiforme short-shoots in the mesocosm produced 8 new leaves for a leaf PI of $70 \mathrm{~d}$. We also calculated leaf PI for $S$. filiforme short-shoots from a short-term summer field study in the Indian River Lagoon near Fort Pierce (Fry 1983). During August new leaves were produced every 20 to $22 \mathrm{~d}$, nearly twice as fast as we measured in Florida Bay.

The 2 species commonly found growing in association with Syringodium filiforme, Thalassia testudinum and Halodule wrightii, have leaf PI ranging from 9 to 26 d (Patriquin 1973, Durako 1994, Gallegos et al. 1994, Marba et al. 1994, Lee \& Dunton 1997). Four of 7 seagrass species examined in a tropical Philippine seagrass meadow had leaf PI ranging from 9 to $13 \mathrm{~d}$ (Vermaat et al. 1995). The longest PI (33 d) in the Philippine meadow was recorded for a congener of $S$. filiforme, 
Syringodium isoetifolium. In comparison with other differentiated seagrasses, the genus Syringodium may have significantly slower leaf formation rates than other genera. Even though the leaf formation rate for the Florida Bay $S$. filjforme was faster than either the Mexican population or the mesocosm plants, 40 days is still among the slowest recorded for any seagrass in the world.

By calibrating the rapid formation of the first 3 to 4 leaves on Syringodium filiforme short-shoots we were able to assign an absolute chronological time scale to short-shoot age. Most of the population was younger than $1 \mathrm{yr}$, with median short-shoot ages ranging from 150 to $190 \mathrm{~d}$ (Figs. 3 \& 4, Table 3). The skewed age distributions for all dates suggested a nearly continuous seasonal and interannual recruitment process in the population during the sampling period. Very young short-shoots $(<100 \mathrm{~d}$ old $)$ were present even in mid-winter at site 4 (Fig. 4). The presence of a large peak at 5 leaf PI in the January 1997 age frequency histogram indicates that new short-shoots are still being produced during the winter months. Short-shoot recruitment appears to be greatest in the spring, as evidenced by the shape of the pooled spring age frequency distribution (Fig. 3). The difference in the numbers of short-shoots in the 0.5 to 1.0 yr ( 6 to $13 \mathrm{PI}$ ) age class between the spring and fall pooled age frequency histograms may be due to reduced recruitment during the fall and loss of short-shoots as a result of flowering mortality. Unlike Thalassia testudinum and Halodule wrightii short-shoots, which produce distinct flowering stalks branching from the main vertical axis, entire $S$. filiforme short-shoots transform from vegetative shortshoots to sexual, flowering short-shoots. This appears to be a terminal event, as unbranched short-shoots which flower have been observed to die soon after release of pollen or after the seeds dropped (pers. obs.). We observed large numbers of flowering short-shoots (125 to $500 \mathrm{~m}^{-2}$ ) during April and May surveys and a smaller amount of flowering short-shoots (40 to $110 \mathrm{~m}^{-2}$ ) in January. No flowering short-shoots were seen in the October samples.

Three age classes were evident in the distributions, short-shoots $\leq 12$ leaf PI (year 1), short-shoots between 12 and 21 leaf PI (year 2), and short-shoots $>21$ leaf PI (year 3) (Figs. $3 \& 4$ ). However, very few short-shoots appear to live beyond year 2 and the oldest shortshoot recorded. was approximately 3.5 yr old. Despite morphological and density differences, the age structure of the Florida Bay population is very similar to the Mexican population, corroborating that Syringodium filiforme has a shorter lifespan and higher shortshoot turnover rate than Thalassia testudinum (Gallegos et al. 1993, 1994, Durako 1994, Jensen et al. 1997).

\section{Vertical growth}

,

Despite having a longer leaf PI than most species, the Syringodium filiforme population in Florida Bay has one of the highest vertical stem growth rates of any seagrass known (Marba et al. 1994, Vermaat et al. 1995, Duarte et al. 1996). Short-shoot stems grew $28.7 \mathrm{~cm}$ during their first year and $5.7 \mathrm{~cm}$ the second year for an overall average of $17 \mathrm{~cm} \mathrm{yr}^{-1}$. During the estimated life span of a short-shoot in the Mexican

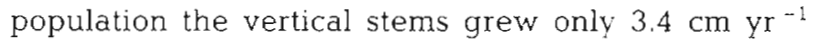
(Gallegos et al. 1994). The higher growth rate in the Florida population was due to both a shorter leaf PI there and the formation of larger internodes on the vertical stems (Fig. 5). Ranging in lengths up to $7.5 \mathrm{~cm}$, and averaging more than $2.0 \mathrm{~cm}$ node $^{-1}$ short-shoot ${ }^{-1}$, the vertical internodes in the $S$. filiforme population in Florida are among the largest known for any seagrass. In the Mexican S. filiforme population, vertical internodes were between 0.1 and $1 \mathrm{~cm}$, with alternating cycles of minimum and maximum values generally $\leq 1 \mathrm{~cm}$ (Gallegos et al. 1994). Where vertical internode lengths have been reported for undisturbed populations of other differentiated seagrass species, they range between 0.05 and $0.8 \mathrm{~cm}$ (Gallegos et al. 1994, Marba et al. 1994, Marba \& Duarte 1995), still considerably less than that for the $S$. filiforme in outer Florida Bay

Other examples of vertical growth comparable to the Syringodium filiforme population in Florida have been observed at locations where seagrasses were experiencing sediment accretion. The maximum vertical internode lengths of Cymodocea nodosa short-shoots buried by subaqueous sand dunes were $2 \mathrm{~cm}$, while under normal conditions the internodes are usually $\leq 0.5 \mathrm{~cm}$ (Marba \& Duarte 1995). Similarly, the vertical internode lengths of Thalassia testudinum increased 5 -fold while the short-shoots produced new leaves $25 \%$ faster in a meadow which was partially buried during Hurricane Gilbert (Marba et al. 1994). Even with a shorter leaf PI, the highest vertical stem growth rate for $T$. testudinum experiencing burial was $9 \mathrm{~cm}$ $\mathrm{yr}^{-1}$ (Gallegos et al. 1994, Marba \& Duarte 1995), which is still considerably less than the rate sustained by $S$. filiforme for $2 \mathrm{yr}$ of growth in outer Florida Bay. Presumably, the longer internode lengths and faster leaf PI for $T$ testudinum and $C$. nodosa short-shoots maintain the vertically growing meristems close to the sediment surface, whereas, with the exception of the first 2 or 3 vertical internodes, all of the $S$. filiforme stem growth in the Florida population occurred above the sediment surface.

Two genera, Amphibolis and Thalassodendron, are the only other seagrasses known from undisturbed populations to regularly produce vertical short-shoot 
stems above the sediment surface. Thalassodendron ciliatum has vertical growth rates comparable to Syringodium filiforme in Florida Bay, with highest rates $\left(15.9 \mathrm{~cm} \mathrm{yr}^{-1}\right)$ and the longest internodes $(0.5$ to $1.25 \mathrm{~cm}$ ) occurring in the youngest shoots (Duarte et al. 1996). And like those of $S$. filiforme, $T$. ciliatum stem internode size $(<0.5 \mathrm{~cm})$ and growth rate $\left(5.9 \mathrm{~cm} \mathrm{yr}^{-1}\right)$ both decline with short-shoot age. These 2 species also have similar maximum vertical stem lengths, and their vertical meristems divide and form new vegetatively growing axes high up in the canopy.

The capability of Syringodium filiforme to proliferate vertically enables this species to form populations of multi-layered canopies structured by several shortshoot age categories which allocate relatively different proportions of biomass to leaves and stems (Figs. 1, 6 $\& 7$ ). The youngest short-shoots, recently formed by division of the horizontal rhizome meristems buried in the sediment, mature rapidly and have relatively higher ratio of leaf to stem mass than older shortshoots. The photosynthetic tissue of short-shoots $\leq 1 \mathrm{yr}$ old is distributed throughout the vertical height of the canopy and is exposed to a range of light regimes (Figs, $1 \& 6$ ). For short-shoots $\geq 1$ yr old, the proportion of stem biomass exceeds the leaves because the leaves have become smaller. These relatively shorter leaved shoots are elevated up near the top of the canopy into the highest light regime by the non-photosynthetic stem tissue (Figs. 1 \& 7). Overall, the stems and sheaths account for more than $70 \%$ of the total aboveground plant biomass and add a considerable amount of respiratory tissue to the plant population (sensu Fourqurean \& Zieman 1991) (Fig. 7). The elongated stems raising the leaves to the top of the canopy increase both the amount of non-photosynthetic respiratory tissue and the distance between leaves on adjacent short-shoots in the clonal fragments. In the older age classes, the leaves on 2 adjacent short-shoots may be separated by more than 0.5 to $1.0 \mathrm{~m}$ of stem and horizontal rhizome. If the increased distance between short-shoots affects clonal integration, the smaller leaves associated with aging of the short-shoots may be a morphological response to the physiological cost (respiration) of transporting materials longer distances in the non-photosynthetic tissue (e.g. gases, inorganic nutrients, carbohydrates). This may contribute to the senescence of older short-shoots and limit the maximum size and age a short-shoot can reach.

Alternatively, the relatively smaller leaves on the older short-shoots and aerial rhizomes in the canopy may be a morphological response to a higher light regime at the top of the canopy, similar to the leaf length plasticity reported for other seagrasses along vertical water depth and light gradients (Dennison \& Alberte 1986). The aerial rhizomes and vertical meri- stems of Syringodium filiforme branch prolifically (aerial branches), forming multiple shoot apices (Fig. 1C, D) and horizontal rhizome apical meristems (Fig. 1D) (sensu Cambridge et al. 1983). At the 3 study sites in Florida Bay we estimate there are 115 aerial branches $\mathrm{m}^{-2}$ (Fig. 1D) compared with 171 horizontal rhizome branches $\mathrm{m}^{-2}$ (Fig. 1A) buried in the sediments (Kenworthy \& Schwarzschild 1996). The S. filiforme clones benefit from these aerial branches which form an elevated layer of plant biomass which facilitates the acquisition of resources in the water column light and nutrients) and storage of resources in the canopy, and diminishes the requirement for translocation over relatively long distances up and down the stems, yet still allows access to the remainder of the clone and sediment nutrient reservoirs. The multi-layered canopy reduces light penetration, but physiological integration between photosynthetic and non-photosynthetic tissues within the clones could effectively distribute resources among individual $S$. filiforme meristems and short-shoots. Thus, we hypothesize that this plasticity in growth form may minimize the effects of self shading within the portions of the clones growing in the understory and further benefit $S$. filiforme by having a negative effect on competing species. The vertical stems of Thalassia testudinum do not grow as fast as those of $S$. filiforme, nor do they normally grow above the sediment surface, helping explain why the density of $T$. testudinum rarely exceeds 10 short-shoots $\mathrm{m}^{-2}$ in this $S$. filiforme canopy.

This hypothesis is supported by the results of a longterm experiment in Florida Bay seagrass communities, where it was shown that Halodule wrightii can outcompete and displace Thalassia testudinum under nutrient enriched conditions (Fourqurean et al. 1995). Fourqurean et al. (1995) concluded that part of $H$. wrightii's competitive success over the normally dominant $T$. testudinum was due to the production of aerial rhizomes which eventually overgrew, shaded, and displaced the $T$. testudinum canopy. These results contrast with past experimental studies which suggested that $T$. testudinum's dominance in seagrass communities located throughout the tropical Atlantic, Caribbean and Gulf of Mexico can be attributed to its ability to outcompete $S$. filiforme and $H$. wrightii for nutrients in the sediment and light in the water column (Williams 1987, 1990). We do not know what specific combination of environmental conditions retard $T$. testudinum's competitive superiority or enhance other cooccurring species. Future experimental work on the interactions between ambient light regime and available nutrients should provide a better understanding of the mechanisms controlling vertical growth of S. filiforme and the distribution, relative abundance, and species composition of seagrass cornmunities in tropi- 
cal-subtropical systems (sensu Tilman 1985, Fourqurean et al. 1995).

\section{Summary}

The tools provided by the newly developed techniques in seagrass demography are useful in studies of Syringodium filiforme growth and population dynamics. The one-to-one correspondence between the formation of leaves and nodes on the vertical stems of $S$. filiforme make it possible to age and reconstruct the entire growth history of individual short-shoots. Since the population in outer Florida Bay consists mostly of short-shoots less than $1 \mathrm{yr}$ old and none older than $3.5 \mathrm{yr}$, this meadow requires a nearly continuous and relatively high rate of vegetative recruitment to maintain the observed short-shoot densities. The plasticity of vertical stem and leaf growth enables short-shoots to be distributed in a multi-layered canopy with vegetative recruitment of new shoots occurring in both the water column and on the sediment surface. The ecological implications of the wide plasticity of S. filiforme vertical growth is suggested by comparing populations in Florida Bay, the Mexican Caribbean, and the Virgin Islands. These comparisons, and the evidence for luxuriant vertical growth in outer Florida Bay, suggest a need to identify the environmental controls responsible for stimulating vertical growth. Future research focusing on the physiological mechanisms which couple the environmental signals to the physical structure and architecture of the seagrasses may help explain the growth and species composition of seagrass meadows throughout the southeastern U.S., Gulf of Mexico, and Caribbean Basin.

Acknowledgements. This study was funded by the National Oceanic and Atmospheric Administration's Sanctuaries and Reserves Division, Florida Keys National Marine Sanctuary (FKNMS), Damage Assessment Center, and Restoration Center. We thank Paula Whitfield, Beaufort Laboratory, NMFS, Beaufort, NC, Harold Hudson and Bill Goodwin, FKNMS, and many others who contributed their time to this study.

\section{LITERATURE CITED}

Brouns JJWM (1985) The plastochrone interval method for the study of the seagrasses; possibilities and limitations. Aquat Bot 21:71-88

Cambridge $\mathrm{ML}$, Carstairs SA, Kuo J (1983) An unusual method of vegetative propagation in Australian Zosteraceae. Aquat Bot 15:201-203

Caye G, Meinez A (1985) Observations on the vegetative development, flowering and seeding of Cymodocea nodosa (Ucria) Ascherson on the Mediterranean coasts of France. Aquat Bot 22:277-289

Continental Shelf Associates, Inc. and Geonex Martel, Inc. (1991) Southwest. Florida nearshore benthic habitat study, narrative report. OCS Study MMS 89-0080. U.S. Dept of the Interior, Minerals Management Service, Gulf of Mexico OCS Regional Office, New Orleans, LA

Dawes CJ, Lawrence JM (1980) Seasonal changes in the proximate constituents of the seagrasses Thalassia testudinum, Halodule wrightii, and Syringodium filiforme. Aquat Bot 8:371-380

den Hartog C (1970) The seagrasses of the world. North-Holland, Amsterdam

Dennison WC, Alberte RS (1986) Photoadaptation and growth of Zostera marina L. (eelgrass) transplants along a depth gradient. J Exp Mar Biol Ecol 98:265-282

Duarte CM, Hemminga MA, Marba N (1996) Growth and population dynamics of Thalassodendron ciliatum in a Kenyan back-reef lagoon. Aquat Bot 55:1-11

Duarte CM, Marba N, Agawin N, Cebrian J, Enriquez S, Fortes M, Gallegos M, Merino M, Olesen B, Sand-Jensen K, Uri J, Vermaat J (1994) Reconstruction of seagrass dynamics: age determinations and associated tools for the seagrass ecologist. Mar Ecol Prog Ser 107:195-209

Duarte CM, Terrados J, Agawin NSR, Fortes MD, Bach S, Kenworthy WJ (1997) Response of a mixed Philippine seagrass meadow to experimental burial. Mar Ecol Prog Ser $147: 285-294$

Durako MJ (1994) Seagrass die-off in Florida Bay (USA) changes in shoot demographic characteristics and population dynamics in Thalassia testudinum. Mar Ecol Prog Ser 1.10:59-66

Durako MJ, Duarte CM (1997) On the use of the reconstructive aging techniques for assessing seagrass demography: a critique of the model test of Jensen et al. (1996). Mar Ecol Prog Ser 146:297-303

Erickson RO, Michelini FJ (1957) The plastochrone index. Am J Bot 44:297-305

Fry B (1983) Leaf growth in the seagrass Syringodium filiforme Kutz. Aquat Bot 16:361-368

Fourqurean JW, Durako MJ, Zieman JC (1997) Seagrass status and trends monitoring. Annual Report to the Florida Keys National Marine Sanctuary Water Quality Protection Program. U.S. Environmental Protection Agency, Region 4, Atlanta GA

Fourqurean JW, Powell GVN, Kenworthy WJ, Zieman JC (1995) The effects of long-term manipulation of nutrient supply on competition between the seagrasses Thalassia testudinum and Halodule wrightii in Florida Bay. Oikos $72: 349-358$

Fourquirean JW, Zieman JC (1991) Photosynthesis, respiration and whole plant carbon budget of the seagrass Thalassia testudinum. Mar Ecol Prog Ser 69:161-170

Gallegos ME, Merino M, Marba N, Duarte CM. (1993) Biomass and dynamics of Thalassia testudinum in the Mexican Caribbean: elucidating rhizome growth. Mar Ecol Prog Ser 95:185-192

Gallegos ME, Merino M. Rodriguez A, Marba N, Duarte CM (1994) Growth patterns and demography of pioneer Caribbean seagrasses Halodule wrightii and Syringodium filiforme. Mar Ecol Prog Ser 109:99-104

Harrison PG (1978) Patterns of uptake and translocation of $C_{14}$ by Zostera americana den Hartog in the laboratory. Aquat Bot 5:93-97

Iverson RL. Bittaker HF (1986) Seagrass distribution in the eastern Gulf of Mexico. Estuar Coast Shelf Sci 22:577-602

Jensen SL, Robbins BD, Bell SS (1997) On the use of the reconstructive technique: cnticisms, comments and questions. Mar Ecol Prog Ser 146:305-309

Kenworthy WJ, Fonseca MS (1996) Light requirements of seagrasses Halodule wrightii and Syringodium filiforme de- 
rived from the relationship between diffuse light attenuation and maximum depth distribution. Estuaries 19:740-750

Kenworthy WJ, Schwarzschild AC (1996) Scientific documentation supporting the development of population dynamics models for predicting the recovery of Syringodium filiforme and Thalassia testudinum. Final Report to the Damage Assessment Center, National Oceanic and Atmospheric Administration, Silver Spring. MD

Kuo J, Cook IH, Kirkman H (1987) Observations of propagating shoots in the seagrass genus Amphibolis C. Agardh (Cymodocea). Aquat Bot 27:291-293

Lee K, Dunton KH (1997) Effects of in situ light reduction on the maintenance, growth and partitioning of carbon resources in Thalassia testudinum Banks ex Konig. J Exp Mar Biol Ecol 210:53-73

Libes M, Boudouresque CF (1987) Uptake and long-distance transport of carbon in the marine phanerogam Posidonia oceanica. Mar Ecol Prog Ser 38:177-186

Marba N, Duarte CM (1994) Growth response of the seagrass Cymodocea nodosa to experimental burial and erosion. Mar Ecol Prog Ser 107:307-311

Marba N, Duarte CM (1995) Coupling of subaqueous dune migration and seagrass (Cymodocea nodosa) dynamics. J Ecol 83:381-389

Marba N, Gallegos ME, Merino M, Duarte CM (1994) Vertical growth of Thalassia testudinum: seasonal and intrannual variability. Aquat Bot 47:1-11

Patriquin DG (1973) Estimation of growth rate, production and age of the marine angiosperm Thalassia testudinum Konig. Carib J Sci 13:111-123

Patriquin DG (1975) 'Migration' of blowouts in seagrass beds at Barbados and Carriacou, West Indies, and its ecological

Editorial responsibility: Kenneth Heck (Contributing Editor), Dauphin Island, Alabama, USA and geological implications. Aquat Bot 1:163-189

Short FT, Montgomery J, Zimmermann CF, Short CA (1993) Production and nutrient dynamics of a Syringodium filiforme Kutz. seagrass bed in Indian River Lagoon, Flonda Estuaries 16:323-334

Terrados J (1997) Is light involved in the vertical growth response of seagrasses when buried by sand? Mar Ecol Prog Ser 152:295-299

Terrados J, Duarte CM, Kenworthy WJ (1997) Experimental evidence for apical dominance in the seagrass Cymodocea nodosa (Ucria). Mar Ecol Prog Ser 148:263-268

Tilman D (1985) The resource ratio hypothesis of succession Am Nat 125:827-852

Tomasko DA, Dawes CJ (1989) Evidence for physiological integration between shaded and unshaded short shoots of Thalassia testudinum. Mar Ecol Prog Ser 54:299-305

Tomlinson PB (1974) Vegetative morphology and meristem dependence-the foundation of productivity in seagrasses. Aquaculture 4:107-130

Vermaat JE, Agawin NSR, Duarte CMD, Fortes MD, Marba $N$, Uni JS (1995) Meadow maintenance, growth and productivity of a mixed Philippine seagrass bed. Mar Ecol Prog Ser 124:215-225

Williams SL (1987) Competition between the seagrasses Thalassia testudinum and Syringodium filiforme in a Caribbean lagoon. Mar Ecol Prog Ser 35:91-98

Williams SL (1990) Experimental studies of Caribbean seagrass bed development. Ecol Monogr 60:449-469

Zieman JC (1982) The ecology of seagrasses of south Florida a community profile. FWS/QBS-82/25. US Fish and Wildlife Services, Office of Biological Services, Washington, $\mathrm{DC}$

Submitted: October 16, 1997; Accepted: July 16, 1998 Proofs received from author(s): October 22, 1998 